GEOLOGICAL SURVEY CIRCULAR 605

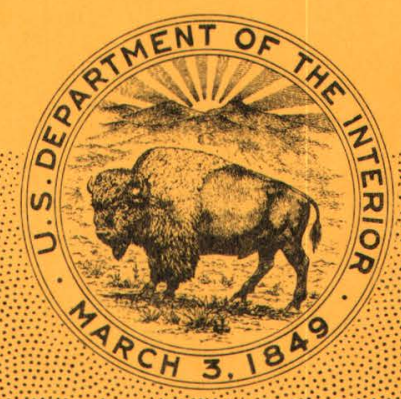

\title{
Gold Distribution on \\ the Sea Floor off \\ the Klamath Mountains \\ California
}





\section{Gold Distribution on \\ the Sea Floor off \\ the Klamath Mountains \\ California}

By George W. Moore and Eli A. Silver

GEOLOGICAL SURVEY CIRCULAR 605

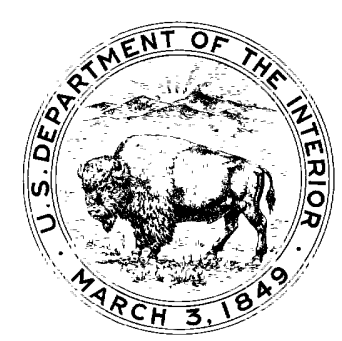


United States Department of the Interior

WALTER J. HICKEL, Secretary

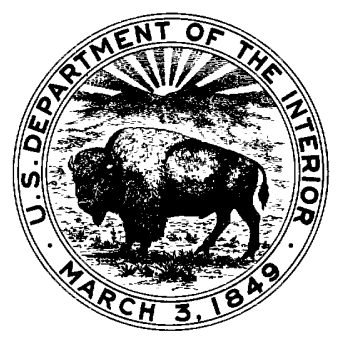

Geological Survey

William T. Pecora, Director

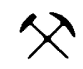

First printing 1968

Second printing 1970 
Abstract

Introduction-1...

Field and laboratory methods -...

Gold distribution -...

Origin of the anomalously high gold values -

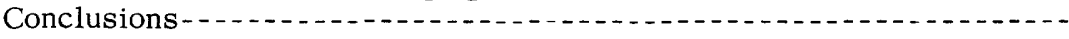

References cited

\section{ILLUSTRATIONS}

Figure 1. Index map showing location of the project area and the

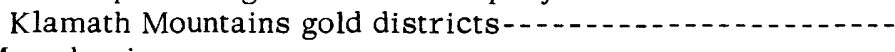
2-4. Map showing-

2. Location and gold content of the samples -.............

3 . Weight percent of minerals heavier than methylene iodide in the samples..................

4. Relationship between gold anomalies and bedrock géology -...

TABLE

Page

Table 1. Location, depth, and analyses of samples 



\title{
Gold Distribution on the Sea Floor off the Klamath Mountains, California
}

\author{
By George W. Moore and Eli A. Silver
}

\begin{abstract}
Analyses of 82 samples collected from the surface of the continental shelf between the Oregon-California border and Eureka, Callf., indicate that the background gold content on this shelf is about $0.1 \mathrm{ppb}$ (part per billion). Four anomalous tracts, which range in extent from 10 to 30 square kilometers, have gold values above $10 \mathrm{ppb}$, and the $\mathrm{r}$ iches t sample contains $390 \mathrm{ppb}$. The anomalous areas seem to lack a close correlation with water depth, but they are related to areas underlain by soft Cenozoic strata that contain small quantities of dispersed gold originally derived from lodes in the Klamath Mountains. This relationship suggests that the offshore gold accumulations are lag concentrates produced from the Cenozoic deposits by wave erosion during the postglacial rise in sea level. Gold contents at the surface are too low for economic recovery, and drilling will be required to determine whether the anomalous areas are underlain by higher grade material.
\end{abstract}

\section{INTRODUCTION}

As part of the U.S. Geological Survey's Heavy Metals program, resource appraisals have been undertaken on areas of the continental shelf that lie offshore from mining districts on land that in the past have produced significant quantities of metals, such as gold and platinum. The shelf off northernmost California adjacent to the gold districts of the Klamath Mountains is one such area selected for study (fig. 1). To perform the investigation, a joint research contract was entered into with Scripps Institution of Oceanography. This report summarizes the results of the first year's work.

The initial phase of the investigation has provided a fair understanding of the areal distribution of gold in the surface layer of sediment for a distance of about 150 kilometers along the northern California continental shelf. The sample spacing is close enough to define approximately shapes of areas with high gold values and to permit consideration of the significance of their relationship to other aspects of the geology.

A companion project dealing with the continental shelf off southern Oregon, directly north of this project area, is in progress through a joint research contract with Oregon State University. Preliminary reports have recently been issued on the first findings of that study (Clifton, 1968; Kulm and others, 1968).

Sampling was done from Scripps Institution of Oceanography's research vessel Oconostota in August and Septem ber 1967, and we are indebted to the officers, crew, and graduate students aboard the ship, who made the project a success. After the cruise, Norman Schumacher, of Scripps Institution of Oceanography, prepared the s a m ples for chemical analysis and was responsible for determining the physical properties of the sediment.

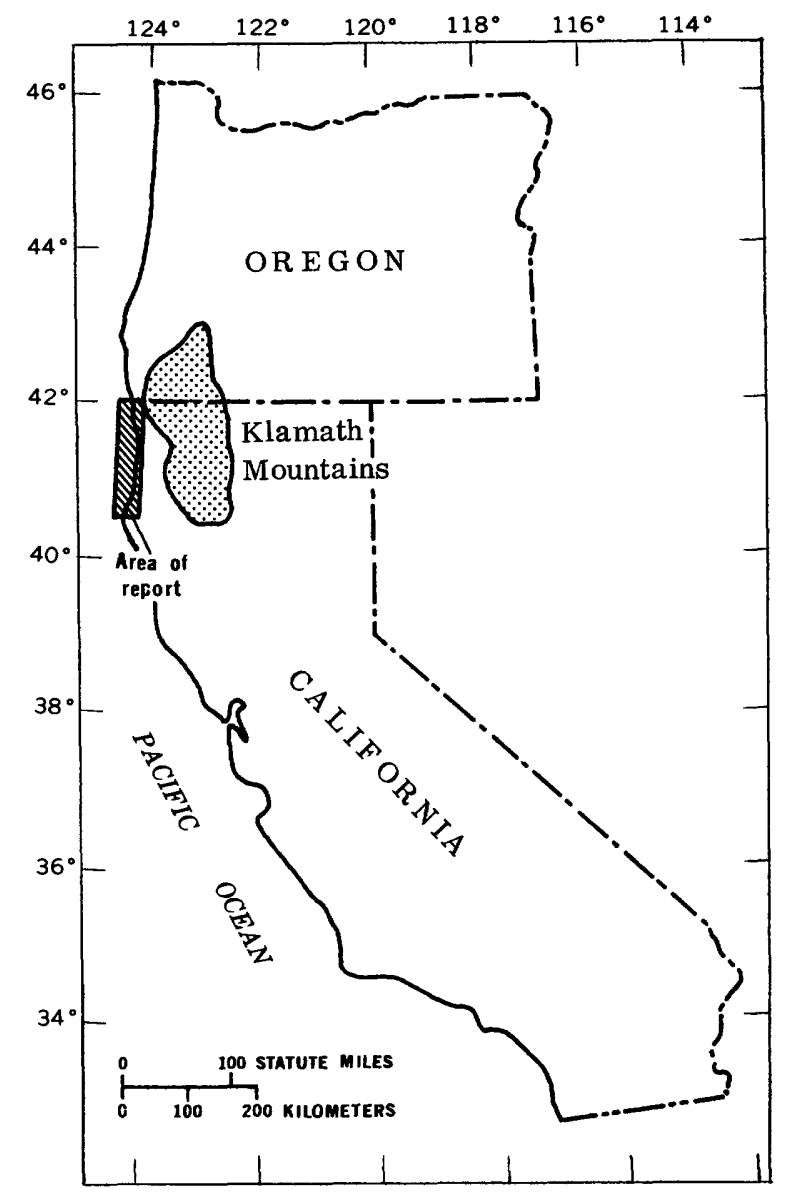

Figure 1.--Index map showing location of the project area and the Klamath Mountains gold districts. 


\section{FIELD AND LABORATORY METHODS}

Most of the 82 samples considered in this report were taken with a sediment dredge developed by Andre M. Rosfelder, of Scripps Institution of Oceanography. Material enters the $\mathrm{dredge}$ through a cone-shaped scoop, from which it passes into a watertight bag that holds about 15 kilograms of sediment. The dredge was particularly effective on the homogeneous and firmly compacted sand of the shelf, which commonly resists penetration by samplers of the snapper type. During dredging operations, the device remained on the bottom for about 1 minute, while the ship drifted at 1-3 kilometers per hour. Sample locations are based on radar ranges and bearings to headlands, recorded at the time the dredge touched the bottom.

The median diameter of the grains in the offshore samples ranges from 0.06 to $0.15 \mathrm{~mm}$ (millimeter). Inasmuch as a single grain of gold of these grain sizes is detectable by chemical analysis, a fairly large fraction from an original sample is required for an analysis to be representative, and the coarsest samples require the largest fractions. For each sample, we endeavored to select a weight for analysis according to grain size such that if the sample were to contain $10 \mathrm{ppb}$ (parts per billion) gold, the number of gold grains theoretically expected would be 1.8 , a value that provides an optimum 72.6 percent chance that the fraction will contain between 1 and 3 grains of gold (Dixon and Massey, 1957, table A-15) and hence will give an analysis between 5 and $15 \mathrm{ppb}$. The calculations, which assume that the gold grains are the size of the median diameter of the whole sample, were based on the relation

$$
\underline{\mathrm{n}}=1 / 6 \pi \underline{\mathrm{D}}^{3} \rho \delta^{-1} \lambda \text {, }
$$

where

$\underline{\mathrm{n}}=$ weight in grams,

$\underline{D}=$ the median diameter in centimeters,

$\rho=$ the density of native gold in grams per cubic centimer,

$\delta=$ the grade in parts per billion, and

$\lambda=$ the expected number of gold grains.

When $\rho=17 \mathrm{~g} / \mathrm{cm}^{3}, \delta=10 \mathrm{ppb}, \lambda=1.8$, and $\mathrm{D}$ is replaced by $\underline{\mathrm{d}}$ in millimeters, this relation reduces to

$$
\underline{\mathrm{n}}=1.6 \cdot 10^{6} \underline{\mathrm{d}}^{3} \text {. }
$$

As an example, 2100-g fractions were used for samples with a median diameter of $0.11 \mathrm{~mm}$. The precision of analysis would be greater for a sample with a gold content higher than $10 \mathrm{ppb}$, or with a median diameter for gold grains smaller than that of its other grains, as in these cases the analyzed fraction would contain more than the 1-3 grains of gold called for in the equation.

The chemical analyses were made by atomicabsorption spectrophotometry according to the method developed by VanSickle and Lakin(1968). The digestion and extraction procedures used in this method require that the sample not exceed a weight of $100 \mathrm{~g}$; hence, the heavy minerals in the fractions were first concentrated to less than $100 \mathrm{~g}$ by separation with heavy liquids. Bromoform, with a specific gravity of 2.85 , was used in a first stage of separation, followed by methylene iodide, with a specific gravity of 3.3. Fractions from sand samples were separated in $100-\mathrm{g}$ batches in steep-walled glass funnels 15 centimeters in diameter; two silt samples were separated in $40-\mathrm{g}$ batches in a centrifuge.

Gold values for 61 of the samples studied are given in table 1 and contoured in figure 2. The values reported are the calculated gold content of the samples before concentration. Gold analyses were not obtained for the 21 remaining samples, but comparison of figure 2 with figure 3 , which is a plot of the percent of each sample that is heavier than methylene iodide, shows that in areas for which both percent heavier than methylene iodide and gold analyses are available, the two show a fairly close correlation. Therefore, the methylene iodide percentages can be used to estimate the probable gold content.

\section{GOLD DISTRIBUTION}

Surface sediment in four a reas on the northernmost California continental shelf contain gold values greater than $10 \mathrm{ppb} . \underline{1}$ These areas are north of Point St. George, west of Crescent City, south of the mouth of the Klamath River, and north of Trinidad Head. The highest value obtained in this investigation, $390 \mathrm{ppb}$, was in a sample from the area north of Trinidad Head. Background gold content is about $0.1 \mathrm{ppb}$. No clear-cut relationship appears to exist between water depth and gold content. The four samples that define the gold anomaly north of Trinidad Head were all collected at depths ranging from 20 to $22 \mathrm{~m}$ (meters), but no other samples collected at other depths in this area were analyzed. The anomalous samples south of the Klamath River came from depths ranging from 16 to $27 \mathrm{~m}$, those north of Point St. George, from depths of 18 to $29 \mathrm{~m}$, and the sample west of Crescent City, from $42 \mathrm{~m}$ depth. Samples with only background gold values occur at similar depths near each of these anomalously rich areas.

The absolute ratio between gold and other heavy minerals changes systematically toward the south. For samples of similar gold content, the percent heavier than methylene iodide decreases by a factor of about 4 from the north end of the project area to the south end (table 1). Ch rom ium content (table 1) similarly is much greater north than south of Point St. George, which lies at $41^{\circ} 47^{\prime} \mathrm{N}$. The analyses also show a poor correlation between chromium and gold. The available evidence indicates mixing of a chromium-bearing

1/ Based on a price of $\$ 35$ per ounce for gold, $10 \mathrm{ppb}$ is equivalent to 1 cent per ton, or 1.6 cents per cubic yard. 


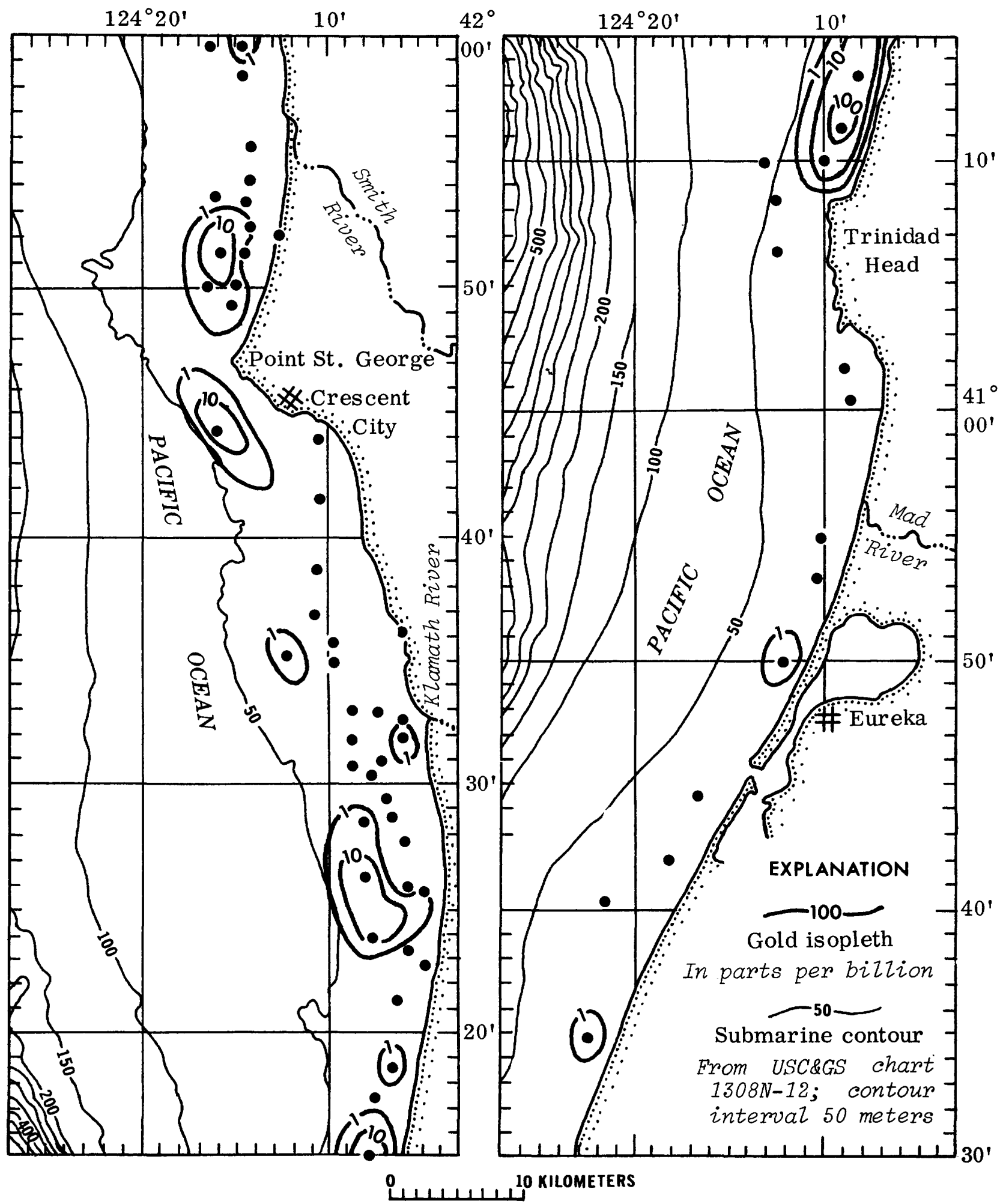

Figure 2.--Map showing location and gold content of the samples.

heavy-mineral suite from the north with a gold-bearing heavy-mineral suite derived from the Klamath Mountains to the east.

\section{ORIGIN OF THE ANOMALOUSLY HIGH GOLDVALUES}

The rather broad depth range within which the gold anomalies occur and their discontinuous nature along the coast suggest to us that they do not occur on relict beaches, in the sense of being at stillstands of Pleistocene sea level. The gold anomalies do bear a relationship to the bedrock geology, however, and this may be genetically significant. The offshore geology of part of the project area has been reported on earlier (Moore and Silver, 1968), and mapping by acoustic- 


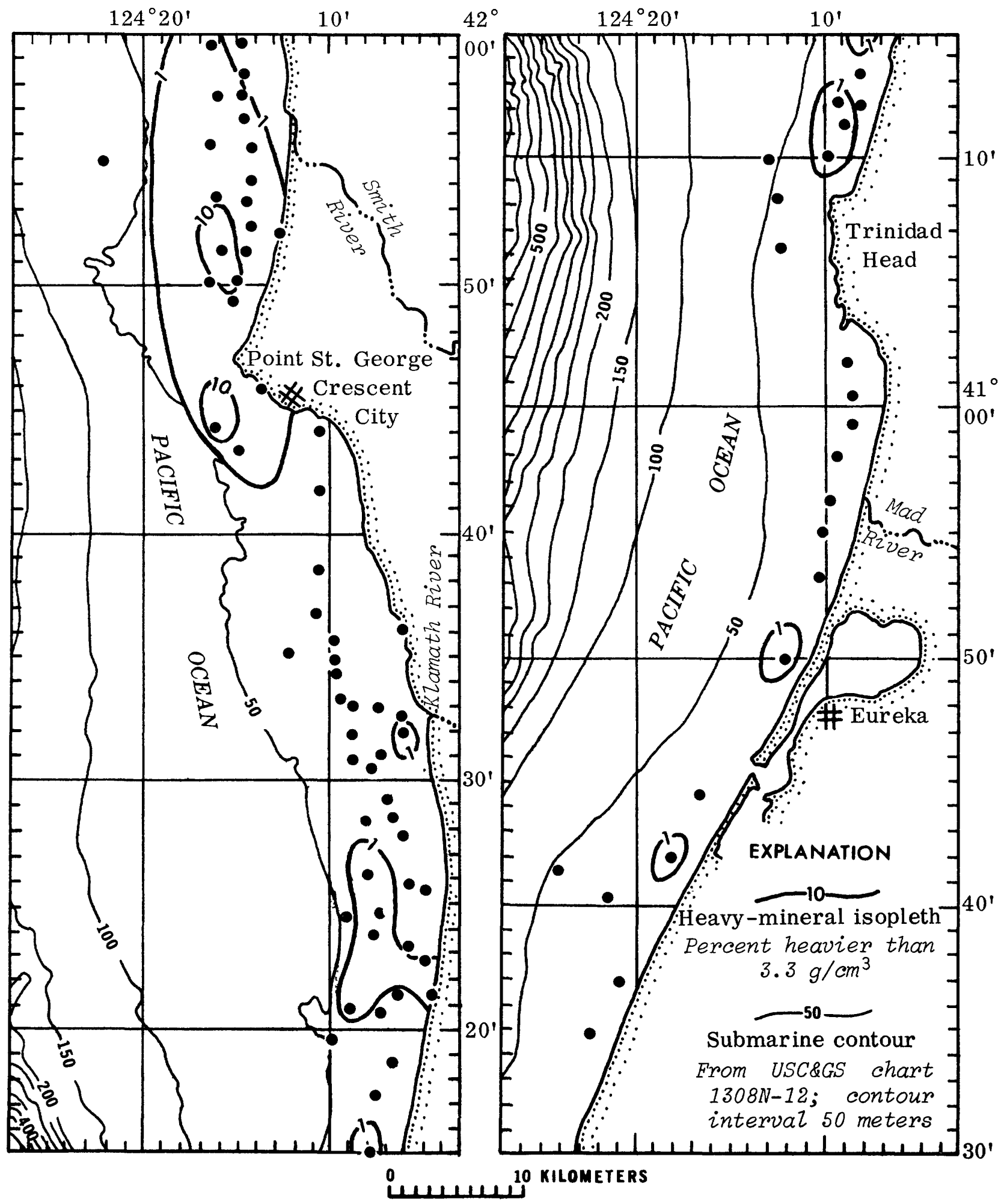

Figure 3.--Map showing weight percent of minerals heavier than methylene iodide in the samples.

reflection profiling methods of the remainder of the area sampled for gold has now been completed. This mapping shows that a single common denominator relates all the areas of anomalously high gold content to the bedrock geology. Each such area overlies a northwest-trending syncline containing upper Cenozoic deposits that carry small quantities of dispersed gold, originally derived from lodes in the Klamath Mountains (fig. 4). This relationship is true also of two minor anomalies at the south end of the area near Eureka (fig. 2).

To explain the gold anomalies, we offer the following hypothesis: During the Holocene rise of sea level that 


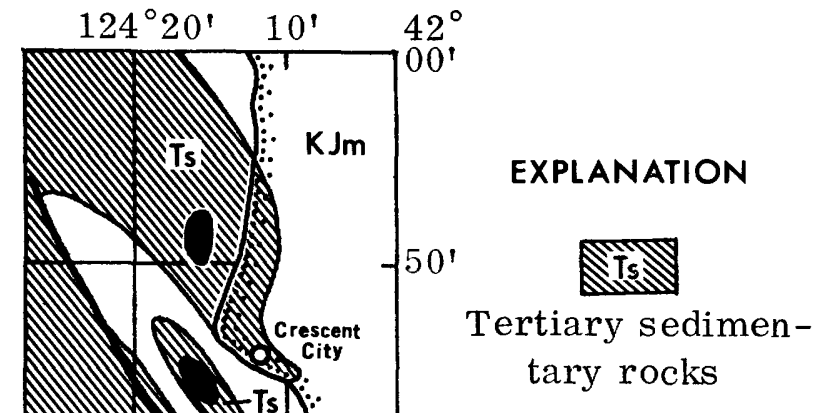

$\mathrm{KJm}$

Cretaceous and Jurassic metamorphic rocks

$30^{\prime}$

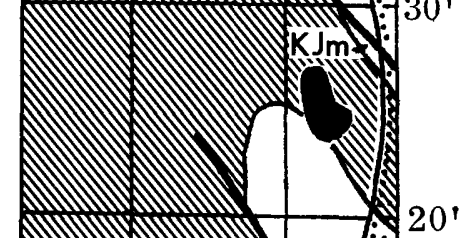

Contact

Cenozoic fault

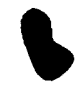

Area where surface sediment contains more than 10 parts per billion gold

O 10 KILOMETERS

flowed the Wisconsin Glaciation, encroaching waves attacked and reworked the soft gold-bearing Cenozoic deposits. Other constituents of the deposits were transported away by the attacking waves, and the gold accumulated offshore as a lag concentrate. Acoustic-reflection profiles indicate that the postglacial deposits in the areas of the anomalies are as thick as 10 meters.

\section{CONCLUSIONS}

Surface sediment in localized areas on the northern California continental shelf contains gold that occurs as probable lag accumulations above synclinal bodies of soft upper Cenozoic material that was eroded by waves along the shore of the rising postglacial sea. Each of four anomalies in which the gold content exceeds $10 \mathrm{ppb}$ covers an area of more than 10 square kilometers, and the richest individual sample contains $390 \mathrm{ppb}$ gold. The gold content of the surface sediment is too low to be of e con om i c significance, and drilling will be necessary to provide information on the distribution of gold at depth within the deposits and on the possible occurrence of minable gold resources below the anomalies.

\section{REFERENCES CITED}

Clifton, H. E., 1968, Gold distribution in surface sediments on the continental shelf off southern Oregon: A preliminary report: U.S. Geol. Survey Circ. 587, $6 \mathrm{p}$.

Dixon, W. J., and Massey, F. J., Jr., 1957, Introduction to statistical analysis, 2d ed.: New York, McGraw-Hill, Inc., 488 p.

Kulm, L. D., Heinrichs, D. F., Buehrig, R. M., and Chambers, D. M., 1968, Evidence for possible placer accumulations on the southern Oregon continental shelf: Ore Bin, v. 30, p. 81-104.

Moore, G. W., and Silver, E. A., 1968, Geology of the Klamath River delta, California: U.S. Geol. Survey Prof. Paper 600-C, p. C144-C148.

VanSickle, G. H., and Lakin, H. W., 1968, An atomicabsorption method for the determination of gold in large samples of geologic materials: LI.S. Geol. Survey Circ. 561, 4 p. 
Table 1.--Location, depth, and analyses of the samples

[Altitude of beach samples above mean lower low water indicated by + in depth column; heavy-liquid separations by N. Schumacher; gold analyses by W. L. Campbell, T. G. Ging, R. F. Hansen, R. Leinz, M. S. Rickard, T. M. Stein, and Z. C. Stephenson; chromium analyses by J. P. Cahill, C. Huffman, V. E. Shaw, and J. A. Thomas]

\begin{tabular}{|c|c|c|c|c|c|c|c|}
\hline \multicolumn{2}{|c|}{ Location } & \multirow{2}{*}{$\begin{array}{l}\text { Depth } \\
\text { (meters) }\end{array}$} & \multirow{2}{*}{$\begin{array}{c}\text { Median } \\
\text { diameter } \\
\text { (millimeters) }\end{array}$} & \multirow{2}{*}{$\begin{array}{l}\text { Heavier than } \\
\text { bromoform } \\
\text { (percent) }\end{array}$} & \multirow{2}{*}{$\begin{array}{c}\text { Heavier than } \\
\text { methylene iodide } \\
\text { (percent) }\end{array}$} & \multirow{2}{*}{$\begin{array}{l}\text { Gold } \\
\text { (parts per } \\
\text { billion) }\end{array}$} & \multirow{2}{*}{$\begin{array}{l}\text { Chromium } \\
\text { (percent) }\end{array}$} \\
\hline Lat $\mathrm{N}$ & Long $\mathrm{W}$ & & & & & & \\
\hline $41^{\circ} 59.6^{\prime}$ & $124^{\circ} 16.3^{\circ}$ & 27 & 0.11 & 12.7 & 1.5 & 0.1 & 0.080 \\
\hline $41^{\circ} 59.5^{\prime}$ & $124^{\circ} 14.8^{\prime}$ & 20 & .12 & 5.6 & .8 & 1.0 & .070 \\
\hline $41^{\circ} 58.5^{\prime}$ & $124^{\circ} 14.6^{\prime}$ & 18 & .12 & 6.8 & .8 & .1 & .068 \\
\hline $41^{\circ} 57.6^{\prime}$ & $124^{\circ} 14.9^{\prime}$ & 18 & .12 & 15.0 & 2.1 & -- & .15 \\
\hline $41^{\circ} 57.5^{\prime}$ & $124^{\circ} 16.0^{\prime}$ & 22 & .12 & 21.1 & 4.6 & -- & .15 \\
\hline $41^{\circ} 56.6^{\prime}$ & $124^{\circ} 14.7^{\prime}$ & 18 & .12 & 23.9 & 2.0 & -- & .24 \\
\hline $41^{\circ} 55.7^{\prime}$ & $124^{\circ} 16.4^{\prime}$ & 27 & .11 & 33.0 & 7.2 & -- & .41 \\
\hline $41^{\circ} 55.5^{\prime}$ & $124^{\circ} 14.4^{\prime}$ & 22 & .11 & 25.0 & 4.4 & .7 & .31 \\
\hline $41^{\circ} 55.0^{\prime}$ & $124^{\circ} 21.9^{\prime}$ & 59 & .06 & 6.6 & .8 & -- & -- \\
\hline $41^{\circ} 54.3^{\prime}$ & $124^{\circ} 14.4^{\prime}$ & 18 & .12 & 41.0 & 1.8 & .7 & .43 \\
\hline $41^{\circ} 53.6^{\prime}$ & $124^{\circ} 16.0^{\prime}$ & 27 & .11 & 38.4 & 9.2 & .4 & .62 \\
\hline $41^{\circ} 53.4^{\prime}$ & $124^{\circ} 14.7^{\prime}$ & 18 & .11 & 42.0 & 5.3 & .1 & .31 \\
\hline $41^{\circ} 52.3^{\prime}$ & $124^{\circ} 14.4^{\prime}$ & 18 & .11 & 30.5 & 7.4 & 1.6 & .22 \\
\hline $41^{\circ} 52.1^{\prime}$ & $124^{\circ} 12.8^{\prime}$ & +2 & .43 & 16.4 & 1.7 & .2 & .047 \\
\hline $41^{\circ} 51.5^{\prime}$ & $124^{\circ} 15.8^{\prime}$ & 29 & .11 & 34.7 & 11.5 & 13. & .80 \\
\hline $41^{\circ} 51.4^{\prime}$ & $124^{\circ} 14.6^{\prime}$ & 18 & .12 & 30.6 & 2.3 & .2 & .45 \\
\hline $41^{\circ} 50.3^{\prime}$ & $124^{\circ} 16.3^{\prime}$ & 29 & .12 & 29.5 & 8.4 & 7.1 & .68 \\
\hline $41^{\circ} 50.2^{\prime}$ & $124^{\circ} 15.0^{\prime}$ & 18 & .12 & 37.8 & 12.8 & 4.0 & .68 \\
\hline $41^{\circ} 49.4^{\prime}$ & $124^{\circ} 15.3^{\prime}$ & 18 & .13 & 28.5 & 5.7 & 2.6 & .57 \\
\hline $41^{\circ} 45.9^{\prime}$ & $124^{\circ} 13.8^{\prime}$ & +1 & 1.06 & 24.2 & 2.9 & -- & -- \\
\hline
\end{tabular}


Table 1.--Location, depth, and analyses of the samples--Continued

\begin{tabular}{|c|c|c|c|c|c|c|c|}
\hline \multicolumn{2}{|c|}{ Location } & \multirow{2}{*}{$\begin{array}{l}\text { Depth } \\
\text { (meters) }\end{array}$} & \multirow{2}{*}{$\begin{array}{c}\text { Median } \\
\text { diameter } \\
\text { (millimeters) }\end{array}$} & \multirow{2}{*}{$\begin{array}{c}\text { Heavier than } \\
\text { bromoform } \\
\text { (percent) }\end{array}$} & \multirow{2}{*}{$\begin{array}{c}\text { Heavier than } \\
\text { methylene iodide } \\
\text { (percent) }\end{array}$} & \multirow{2}{*}{$\begin{array}{c}\text { Gold } \\
\text { (parts per } \\
\text { billion) }\end{array}$} & \multirow{2}{*}{$\begin{array}{l}\text { Chromium } \\
\text { (percent) }\end{array}$} \\
\hline Lat $N$ & Long $\mathrm{W}$ & & & & & & \\
\hline $41^{\circ} 44.2^{\prime}$ & $124^{\circ} 15.8^{\prime}$ & 42 & 0.13 & 41.6 & 11.9 & 15. & -- \\
\hline $41^{\circ} 44.1$ & $124^{\circ} 10.7^{\prime}$ & 5 & .14 & 13.1 & .6 & $<.1$ & -- \\
\hline $41^{\circ} 43.2^{\prime}$ & $124^{\circ} 14.6^{\prime}$ & 37 & .12 & 16.9 & 1.9 & -- & -- \\
\hline $41^{\circ} 41.6^{\prime}$ & $124^{\circ} 10.7^{\prime}$ & 18 & -- & 8.0 & .1 & $<.1$ & -- \\
\hline $41^{\circ} 38.6^{\prime}$ & $124^{\circ} 10.7^{\prime}$ & 32 & -- & 6.0 & $<.1$ & $<.1$ & -- \\
\hline $41^{\circ} 36.8^{\prime}$ & $124^{\circ} 10.8^{\prime}$ & 33 & .08 & 2.4 & .2 & .6 & .024 \\
\hline $41^{\circ} 36.2 \prime$ & $124^{\circ} 06.0^{\prime}$ & +1 & -- & 2.7 & .1 & .3 & -- \\
\hline $41^{\circ} 35.8^{\prime}$ & $124^{\circ} 10.0^{\prime}$ & 33 & .09 & 10.8 & .4 & .5 & .049 \\
\hline $41^{\circ} 35.2 '$ & $124^{\circ} 12.4^{\prime}$ & 41 & .09 & 12.9 & .4 & 1.2 & -- \\
\hline $41^{\circ} 35.0^{\prime}$ & $124^{\circ} 10.0^{\prime}$ & 33 & .08 & 2.6 & .1 & .3 & .030 \\
\hline $41^{\circ} 34.2^{\prime}$ & $124^{\circ} 09.5^{\prime}$ & 31 & .09 & 4.1 & .8 & -- & .058 \\
\hline $41^{\circ} 33.5^{\prime}$ & $124^{\circ} 09.0^{\prime}$ & 31 & .10 & 5.6 & .2 & -- & .031 \\
\hline $41^{\circ} 33.1^{\prime}$ & $124^{\circ} 07.8^{\prime}$ & 20 & .11 & 2.2 & .2 & .1 & .030 \\
\hline $41^{\circ} 32.9^{\prime}$ & $124^{\circ} 09.0^{\prime}$ & 31 & .12 & 11.6 & .8 & .7 & .038 \\
\hline $41^{\circ} 32.8^{\prime}$ & $124^{\circ} 06.3^{\prime}$ & 18 & .09 & 9.3 & .9 & .9 & .060 \\
\hline $41^{\circ} 32.0^{\circ}$ & $124^{\circ} 06.3^{\prime}$ & 16 & .11 & 13.4 & 1.6 & 5.3 & .055 \\
\hline $41^{\circ} 31.9^{\prime}$ & $124^{\circ} 09.0^{\prime}$ & 27 & .12 & 15.0 & .8 & .7 & .046 \\
\hline $41^{\circ} 31.2^{\prime}$ & $124^{\circ} 07.5^{\prime}$ & 18 & .12 & 12.5 & .9 & .7 & .047 \\
\hline $41^{\circ} 30.9^{\prime}$ & $124^{\circ} 08.6^{\prime}$ & 27 & .12 & 11.0 & .8 & .5 & .048 \\
\hline $41^{\circ} 30.4^{\prime}$ & $124^{\circ} 08^{\prime} 6^{\prime}$ & 29 & .12 & 3.8 & .4 & .2 & .030 \\
\hline $41^{\circ} 29.3^{\prime}$ & $124^{\circ} 07.2^{\prime}$ & 18 & .12 & 9.6 & .7 & .8 & .045 \\
\hline $41^{\circ} 28.6^{\prime}$ & $124^{\circ} 06.7^{\prime}$ & 18 & -- & 17.3 & .2 & $<.1$ & -- \\
\hline $41^{\circ} 28.5^{\prime}$ & $124^{\circ} 08.3^{\prime}$ & 18 & .12 & 6.3 & .7 & 1.2 & .054 \\
\hline $41^{\circ} 27.6^{\prime}$ & $124^{\circ} 06.0^{\prime}$ & 16 & .12 & 3.0 & .8 & .4 & .038 \\
\hline
\end{tabular}


Table 1.--Location, depth, and analyses of the samples--Continued

\begin{tabular}{|c|c|c|c|c|c|c|c|}
\hline \multicolumn{2}{|c|}{ Location } & \multirow{2}{*}{$\begin{array}{l}\text { Depth } \\
\text { (meters) }\end{array}$} & \multirow{2}{*}{$\begin{array}{c}\text { Median } \\
\text { diameter } \\
\text { (millimeters) }\end{array}$} & \multirow{2}{*}{$\begin{array}{l}\text { Heavier than } \\
\text { bromoform } \\
\text { (percent) }\end{array}$} & \multirow{2}{*}{$\begin{array}{l}\text { Heavier than } \\
\text { methylene iodide } \\
\text { (percent) }\end{array}$} & \multirow{2}{*}{$\begin{array}{c}\text { Gold } \\
\text { (parts per } \\
\text { billion) }\end{array}$} & \multirow{2}{*}{$\begin{array}{l}\text { Chromium } \\
\text { (percent) }\end{array}$} \\
\hline Lat $\mathrm{N}$ & Long $\mathrm{W}$ & & & & & & \\
\hline $41^{\circ} 26.0^{\prime}$ & $124^{\circ} 08.1^{\prime}$ & 27 & 0.12 & 12.0 & 1.4 & 55. & 0.065 \\
\hline $41^{\circ} 25.7^{\prime}$ & $124^{\circ} 05.8^{\prime}$ & 17 & -- & 12.4 & .4 & $<.1$ & -- \\
\hline $41^{\circ} 25.7 \prime$ & $124^{\circ} 05.1$ & 16 & .13 & 12.9 & 1.5 & 9.4 & .040 \\
\hline $41^{\circ} 24.8^{\prime}$ & $124^{\circ} 09.0^{\prime}$ & 46 & .09 & 6.2 & .3 & -- & -- \\
\hline $41^{\circ} 24.6^{\prime}$ & $124^{\circ} 06.9^{\prime}$ & 24 & .13 & 35.5 & 3.6 & -- & -- \\
\hline $41^{\circ} 23.8^{\prime}$ & $124^{\circ} 08.0^{\prime}$ & 27 & .13 & 17.1 & 1.6 & 22 . & .077 \\
\hline $41^{\circ} 23.4^{\prime}$ & $124^{\circ} 05.8^{\prime}$ & 16 & -- & -- & .5 & $<.1$ & -- \\
\hline $41^{\circ} 22.9^{\prime}$ & $124^{\circ} 05.5^{\prime}$ & 15 & .13 & 6.7 & 1.0 & $<.1$ & .024 \\
\hline $41^{\circ} 21.4^{\prime}$ & $124^{\circ} 06.7$ & 15 & .13 & 8.8 & .4 & $<.1$ & .044 \\
\hline $41^{\circ} 21.4^{\prime}$ & $124^{\circ} 04.5^{\prime}$ & +3 & .34 & 41.4 & 5.1 & -- & -- \\
\hline $41^{\circ} 20.9^{\prime}$ & $124^{\circ} 09.0^{\prime}$ & 38 & .12 & 9.4 & 1.4 & -- & .060 \\
\hline $41^{\circ} 20.7$ & $124^{\circ} 07.4^{\prime}$ & 18 & .12 & 1.2 & .1 & -- & .022 \\
\hline $41^{\circ} 19.6^{\prime}$ & $124^{\circ} 09.9^{\prime}$ & 42 & .09 & 1.4 & .7 & -- & .025 \\
\hline $41^{\circ} 18.7^{\prime}$ & $124^{\circ} 07.3^{\prime}$ & 22 & .13 & 10.0 & .7 & 1.2 & .060 \\
\hline $41^{\circ} 17.4^{\prime}$ & $124^{\circ} 07.6^{\prime}$ & 22 & .11 & 6.9 & .5 & $<.1$ & .065 \\
\hline $41^{\circ} 15.2^{\prime}$ & $124^{\circ} 08.0^{\prime}$ & 22 & .12 & 21.3 & 4.1 & 11. & .20 \\
\hline $41^{\circ} 13.4^{\prime}$ & $124^{\circ} 08.3^{\prime}$ & 20 & .13 & 4.6 & .5 & 13. & .044 \\
\hline $41^{\circ} 12.1^{\prime}$ & $124^{\circ} 09.2^{\prime}$ & 22 & .13 & 19.3 & 1.7 & -- & -- \\
\hline $41^{\circ} 12.0^{\prime}$ & $124^{\circ} 08.2^{\prime}$ & 15 & .13 & 12.6 & .6 & -- & -- \\
\hline $41^{\circ} 11.4^{\prime}$ & $124^{\circ} 09.0^{\prime}$ & 20 & .13 & 14.4 & 1.1 & 390. & .098 \\
\hline $41^{\circ} 10.1^{\prime}$ & $124^{\circ} 09.9^{\prime}$ & 20 & .13 & 14.1 & 1.4 & 11. & .10 \\
\hline $41^{\circ} 09.8^{\prime}$ & $124^{\circ} 13.1^{\prime}$ & 53 & .06 & 1.9 & .1 & $<.1$ & .018 \\
\hline $41^{\circ} 08.2^{\prime}$ & $124^{\circ} 12.6^{\prime}$ & 22 & .13 & 2.3 & .1 & $<.1$ & .015 \\
\hline $41^{\circ} 06.3^{\prime}$ & $124^{\circ} 12.5^{\prime}$ & 38 & .13 & 4.6 & .5 & $<.1$ & .041 \\
\hline
\end{tabular}


Table 1.--Location, depth, and analyses of the samples--Continued

\begin{tabular}{|c|c|c|c|c|c|c|c|}
\hline \multicolumn{2}{|c|}{ Location } & \multirow{2}{*}{$\begin{array}{l}\text { Depth } \\
\text { (meters) }\end{array}$} & \multirow{2}{*}{$\begin{array}{c}\text { Median } \\
\text { diameter } \\
\text { (millimeters) }\end{array}$} & \multirow{2}{*}{$\begin{array}{c}\text { Heavier than } \\
\text { bromoform } \\
\text { (percent) }\end{array}$} & \multirow{2}{*}{$\begin{array}{c}\text { Heavier than } \\
\text { methylene iodide } \\
\text { (percent) }\end{array}$} & \multirow{2}{*}{$\begin{array}{l}\text { Gold } \\
\text { (parts per } \\
\text { billion) }\end{array}$} & \multirow{2}{*}{$\begin{array}{l}\text { Chromium } \\
\text { (percent) }\end{array}$} \\
\hline Lat $N$ & Long $\mathrm{W}$ & & & & & & \\
\hline $41^{\circ} 01.4^{\prime}$ & $124^{\circ} 09^{\prime} 1^{\prime}$ & 15 & 0.13 & 1.1 & 0.1 & $<0.1$ & .10 \\
\hline $41^{\circ} 00.4^{\prime}$ & $124^{\circ} 08.8^{\prime}$ & 15 & .13 & .8 & .2 & .1 & .015 \\
\hline $40^{\circ} 59.2^{\prime}$ & $124^{\circ} 08^{\prime} 8^{\prime}$ & 15 & .13 & 1.2 & .1 & .1 & .011 \\
\hline $40^{\circ} 57.9^{\prime}$ & $124^{\circ} 09.5^{\prime}$ & 22 & .13 & 1.6 & .1 & -- & .018 \\
\hline $40^{\circ} 56.3^{\prime}$ & $124^{\circ} 09.8^{\prime}$ & 27 & .14 & 3.7 & .4 & -- & .033 \\
\hline $40^{\circ} 54.9 \cdot$ & $124^{\circ} 10.6^{\prime}$ & 29 & .14 & 7.4 & .4 & .5 & .053 \\
\hline $40^{\circ} 53.2$ & $124^{\circ} 10.6^{\prime}$ & 20 & .15 & 7.6 & .7 & $<.1$ & .060 \\
\hline $40^{\circ} 49.9^{\prime \prime}$ & $124^{\circ} 12.3^{\prime}$ & 18 & .15 & 13.6 & 3.8 & 8.1 & .22 \\
\hline $40^{\circ} 44.4^{\prime}$ & $124^{\circ} 16.8^{\prime}$ & 27 & .14 & 2.2 & .2 & $<.1$ & .011 \\
\hline $40^{\circ} 41.9^{\prime}$ & $124^{\circ} 18.4^{\prime}$ & 31 & .10 & .7 & .1 & $<.1$ & .016 \\
\hline $40^{\circ} 41.4^{\prime}$ & $124^{\circ} 24.0^{\prime}$ & 60 & .10 & .7 & .2 & -- & .018 \\
\hline $40^{\circ} 40.34$ & $124^{\circ} 21.7^{\prime}$ & 27 & .12 & 1.5 & .3 & .3 & .020 \\
\hline $40^{\circ} 37.0^{\prime}$ & $124^{\circ} 20.9^{\prime}$ & 18 & .13 & 2.0 & .2 & -- & .037 \\
\hline $40^{\circ} 34.8^{\prime}$ & $124^{\circ} 22.4^{\prime}$ & 18 & .13 & 2.4 & .4 & 1.2 & .042 \\
\hline
\end{tabular}




